LAW RENCE LIVERMORE N A T IO N A L LABORATORY

DUSEL Facility Cooling Water Scaling Issues

W. D. Daily

April 5, 2011 
This document was prepared as an account of work sponsored by an agency of the United States government. Neither the United States government nor Lawrence Livermore National Security, LLC, nor any of their employees makes any warranty, expressed or implied, or assumes any legal liability or responsibility for the accuracy, completeness, or usefulness of any information, apparatus, product, or process disclosed, or represents that its use would not infringe privately owned rights. Reference herein to any specific commercial product, process, or service by trade name, trademark, manufacturer, or otherwise does not necessarily constitute or imply its endorsement, recommendation, or favoring by the United States government or Lawrence Livermore National Security, LLC. The views and opinions of authors expressed herein do not necessarily state or reflect those of the United States government or Lawrence Livermore National Security, LLC, and shall not be used for advertising or product endorsement purposes.

This work performed under the auspices of the U.S. Department of Energy by Lawrence Livermore National Laboratory under Contract DE-AC52-07NA27344. 


\section{DUSEL Facility Cooling Water Scaling Issues}

Research Memo for Sally Bahowick

For questions contact Bill Daily

\section{Scaling information}

Precipitation (crystal growth) in supersaturated solutions is governed by both kenetic and thermodynamic processes. This is an important and evolving filed of research, especially for the petroleum industry. There are several types of precipitates including sulfate compounds (ie. barium sulfate) and calcium compounds (ie. calcium carbonate). The chemical makeup of the mine water has relatively large concentrations of sulfate as compared to calcium, so we may expect that sulfate type reactions.

The kinetics of calcium sulfate dihydrate (CaSO4•2H20, gypsum) scale formation on heat exchanger surfaces from aqueous solutions has been studied by a highly reproducible technique. It has been found that gypsum scale formation takes place directly on the surface of the heat exchanger without any bulk or spontaneous precipitation in the reaction cell. The kinetic data also indicate that the rate of scale formation is a function of surface area and the metallurgy of the heat exchanger. ${ }^{1}$ As we don't have detailed information about the heat exchanger, we can only infer that this will be an issue for us.

Supersaturations of various compounds are affected differently by temperature, pressure and $\mathrm{pH}$. Pressure has only a slight affect on the solubility, whereas temperature is a much more sensitive parameter (Figure 1). The affect of temperature is reversed for calcium carbonate and barium sulfate solubilities. As temperature increases, barium sulfate solubility concentrations increase and scaling decreases. For calcium carbonate, the scaling tendencies increase with increasing temperature. This is all relative, as the temperatures and pressures of the referenced experiments range from 122 to $356^{\circ} \mathrm{F}$. Their pressures range from 200 to 4000 psi. $^{2}$ Because the cooling water system isn't likely to see pressures above 200 psi, it's unclear if this pressure/scaling relationship will be significant or even apparent.

S.J. Dyer, G.M. Graham / Journal of Petroleum Science and Engineering 35 (2002) 95-107

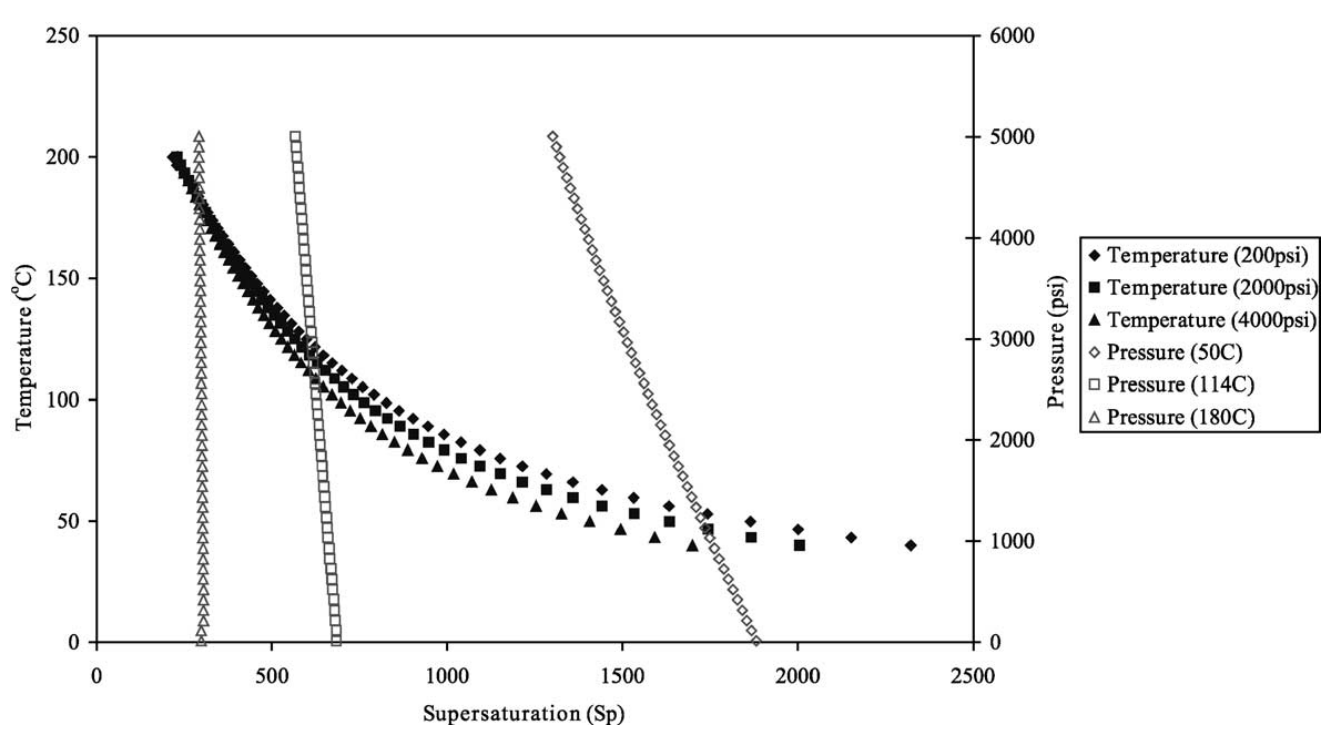

Figure. 1. Predicted barium sulphate supersaturation for the high sulphate scaling brine. Shaded symbols represent the variation in supersaturation with changing temperature at the fixed pressure stated and open symbols represent the variation in supersaturation with changing pressure at the fixed temperature stated.

\footnotetext{
${ }^{1}$ Z. AMJAD, BFGoodrich Chemical Company, Calcium Sulfate Dihydrate (Gypsum) Scale Formation on Heat Exchanger Surfaces: The Influence of Scale ${ }^{2}$ S.J. Dyer, G.M. Graham, Oilfield Scale Research Group, Department of Petroleum Engineering, Heriot-Watt University, Riccarton, Edinburgh, UK, The effect of temperature and pressure on oilfield scale formation, Journal of Petroleum Science and Engineering 35 (2002) 95-107
} 
The most common scale minerals found in the oilfield include calcium carbonates ( $\mathrm{CaCO}$, mainly calcite) and alkaline-earth metal sulfates (barite $\mathrm{BaSO} 4$, celestite $\mathrm{SrSO} 4$, anhydrite CaSO4, hemihydrate $\mathrm{CaSO} 4$ $1 / 2 \mathrm{H} 2 \mathrm{O}$, and gypsum CaSO4 $2 \mathrm{H} 2 \mathrm{O}$ or calcium sulfate). The cause of scaling can be difficult to identify in real oil and gas wells. However, pressure and temperature changes during the flow of fluids are primary reasons for the formation of carbonate scales, because the escape of $\mathrm{CO} 2$ and/or $\mathrm{H} 2 \mathrm{~S}$ gases out of the brine solution, as pressure is lowered, tends to elevate the $\mathrm{pH}$ of the brine and result in super-saturation with respect to carbonates. Concerning sulfate scales, the common cause is commingling of different sources of brines either due to breakthrough of injected incompatible waters or mixing of two different brines from different zones of the reservoir formation. A decrease in temperature tends to cause barite to precipitate, opposite of calcite. In addition, pressure drops tend to cause all scale minerals to precipitate due to the pressure dependence of the solubility product. ${ }^{3}$ And we can expect that there will be a pressure drop across the heat exchanger. Weather or not this will be offset by the rise in pressure remains to be seen. It's typically left to field testing to prove out.

Progress has been made toward the control and treatment of the scale deposits, although most of the reaction mechanisms are still not well understood. Often the most efficient and economic treatment for scale formation is to apply threshold chemical inhibitors. Threshold scale inhibitors are like catalysts and have inhibition efficiency at very low concentrations (commonly less than a few $\mathrm{mg} / \mathrm{L}$ ), far below the stoichiometric concentrations of the crystal lattice ions in solution. There are many chemical classes of inhibitors and even more brands on the market.

\section{System Design Criteria}

The proposed system that is subjected to scaling is a water supply to a heat exchanger/chiller (Figure 2). The water source is groundwater at 150 psi in a 6" pipeline. This water is to be "treated" prior to the heat exchanger. The water is assumed to be discharged in the subsurface without any need for further treatment or pressure requirements.

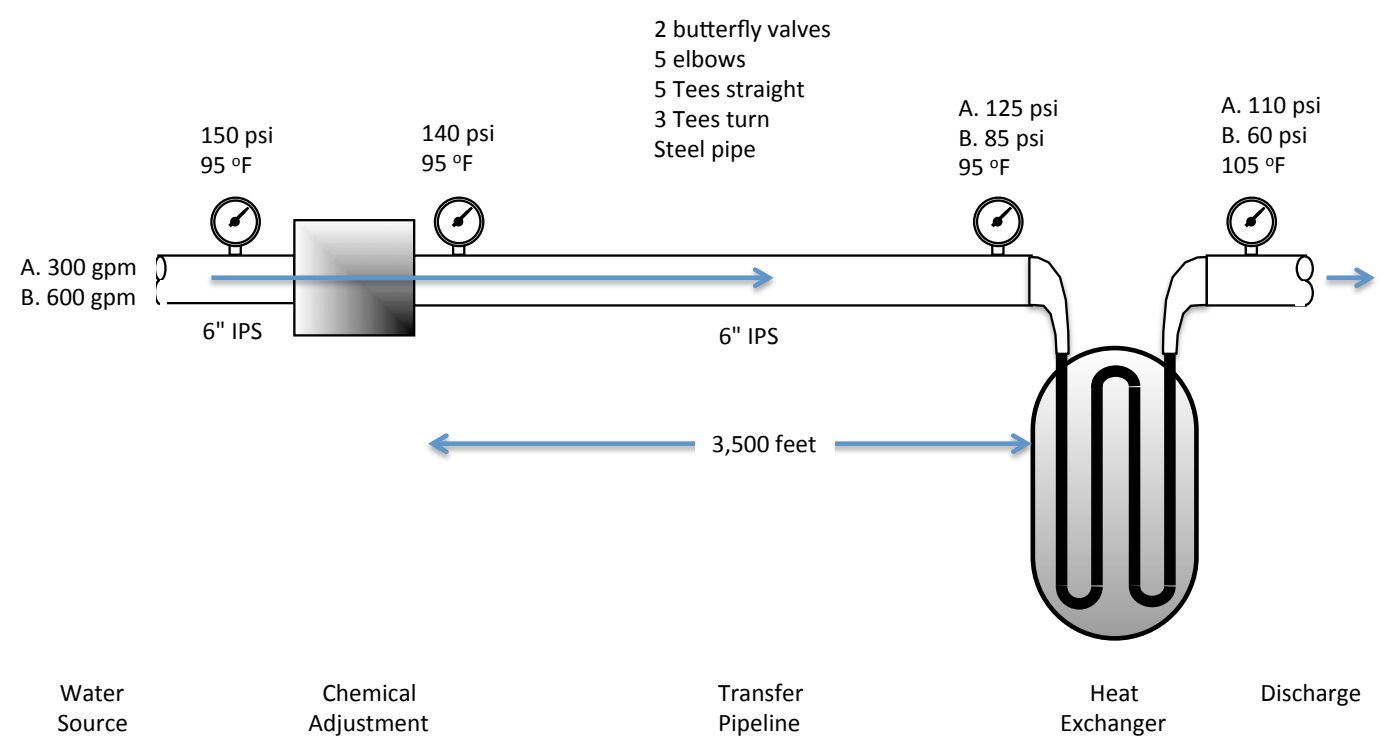

Figure 2. Cooling water treatment supply system

\footnotetext{
${ }^{3}$ He, S.L., Kan, A.T., Tomson, M.B., Rice University; Oddo, J.E., Water Research Institute, A New Interactive Software for Scale Prediction, Control, and Management, SPE Annual Technical Conference and Exhibition, 5-8 October 1997, San Antonio, Texas
} 
The loss of pressure between the water treatment and the heat exchanger is based on the assumptions listed in Figure 2 and the calculation results detailed in Figure 3.

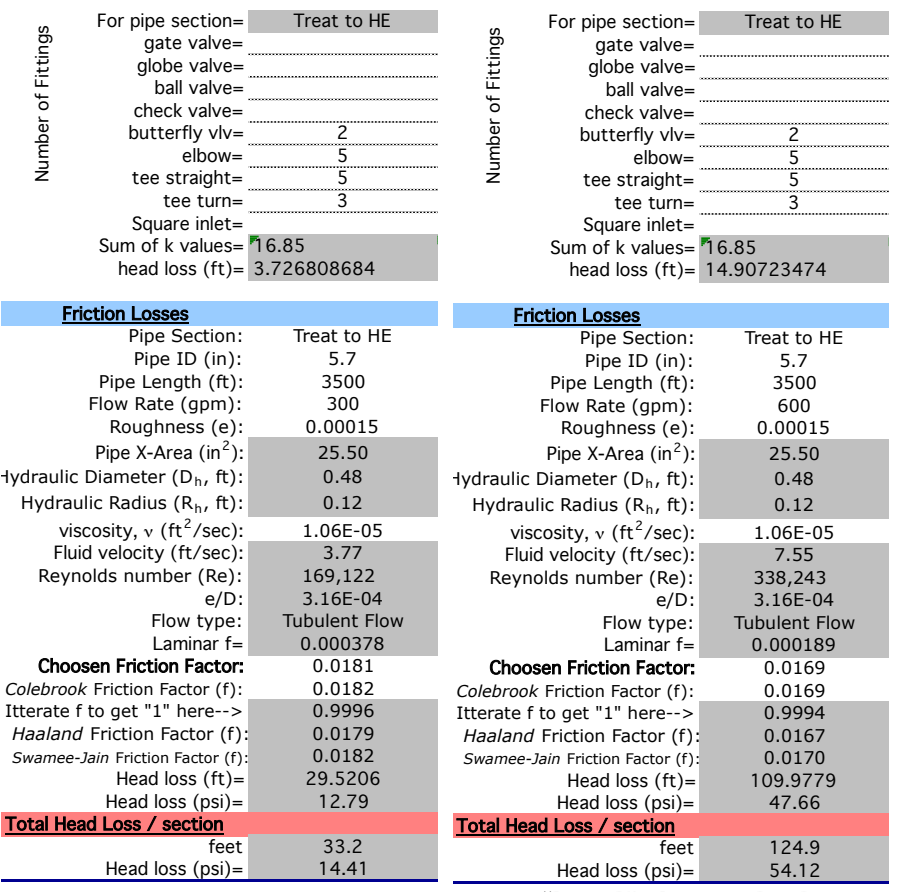

Figure 3. Pressure ("head") loss calculation results for the 3500' 6"dia pipeline.

There are two water chemistries and two flow rates (300 and $600 \mathrm{gpm}$ ) being considered. The resulting four scenarios are presented in Figure 4. 


\begin{tabular}{|c|c|c|c|c|c|c|c|c|c|c|c|}
\hline \multirow{2}{*}{$\begin{array}{l}\text { Scenario } 1 \\
\text { Parameter }\end{array}$} & \multirow[b]{2}{*}{ Value } & \multirow[b]{2}{*}{ Units } & \multicolumn{3}{|l|}{ Scenario 2} & \multicolumn{3}{|l|}{ Scenario 3} & \multicolumn{3}{|l|}{ Scenario 4} \\
\hline & & & Parameter & Value & Units & Parameter & Value & Units & Parameter & Value & Units \\
\hline Flow Rate & 300 & gpm & Flow Rate & 300 & gpm & Flow Rate & 600 & gpm & Flow Rate & 600 & gpm \\
\hline Source Pressure & 150 & psi & Source Pressure & 150 & psi & Source Pressure & 150 & psi & Source Pressure & 150 & psi \\
\hline Heat Exchanger: & & & Heat Exchanger: & & & Heat Exchanger: & & & Heat Exchanger: & & \\
\hline Inlet Pressure & 125 & psi & Inlet Pressure & 125 & psi & Inlet Pressure & 85 & psi & Inlet Pressure & 85 & psi \\
\hline Outlet Pressure & 110 & psi & Outlet Pressure & 110 & psi & Outlet Pressure & 60 & psi & Outlet Pressure & 60 & psi \\
\hline Inlet Temp. & 95 & ${ }^{\circ} \mathrm{F}$ & Inlet Temp. & 95 & ${ }^{\circ} \mathrm{F}$ & Inlet Temp. & 95 & ${ }^{\circ} \mathrm{F}$ & Inlet Temp. & 95 & ${ }^{\circ} \mathrm{F}$ \\
\hline Outlet Temp. & 105 & ${ }^{\circ} \mathrm{F}$ & Outlet Temp. & 105 & ${ }^{\circ} \mathrm{F}$ & Outlet Temp. & 105 & ${ }^{\circ} \mathrm{F}$ & Outlet Temp. & 105 & ${ }^{\circ} \mathrm{F}$ \\
\hline $\mathrm{pH}$ & 6.82 & & $\mathrm{pH}$ & 8.14 & & $\mathrm{pH}$ & 6.82 & & $\mathrm{pH}$ & 8.14 & \\
\hline Conductivity & 5770 & $\mu \mathrm{mhos} / \mathrm{cm}$ & Conductivity & - & $\mu \mathrm{mhos} / \mathrm{cm}$ & Conductivity & 5770 & $\mu \mathrm{mhos} / \mathrm{cm}$ & Conductivity & - & $\mu \mathrm{mhos} / \mathrm{cm}$ \\
\hline TDS & 6130 & $\mathrm{mg} / \mathrm{L}$ & TDS & 3810 & $\mathrm{mg} / \mathrm{L}$ & TDS & 6130 & $\mathrm{mg} / \mathrm{L}$ & TDS & 3810 & $\mathrm{mg} / \mathrm{L}$ \\
\hline TSS & 43.8 & $\mathrm{mg} / \mathrm{L}$ & TSS & 5.6 & $\mathrm{mg} / \mathrm{L}$ & TSS & 43.8 & $\mathrm{mg} / \mathrm{L}$ & TSS & 5.6 & $\mathrm{mg} / \mathrm{L}$ \\
\hline Hardness & 3850 & $\mathrm{mg} / \mathrm{L}$ & Hardness & 1800 & $\mathrm{mg} / \mathrm{L}$ & Hardness & 3850 & $\mathrm{mg} / \mathrm{L}$ & Hardness & 1800 & $\mathrm{mg} / \mathrm{L}$ \\
\hline Non-Metals & & & Non-Metals & & & Non-Metals & & & Non-Metals & & \\
\hline Alkalinity & 160 & $\mathrm{mg} / \mathrm{L}$ & Alkalinity & - & $\mathrm{mg} / \mathrm{L}$ & Alkalinity & 160 & $\mathrm{mg} / \mathrm{L}$ & Alkalinity & - & $\mathrm{mg} / \mathrm{L}$ \\
\hline Bicarbonate & 195 & $\mathrm{mg} / \mathrm{L}$ & Bicarbonate & 195 & $\mathrm{mg} / \mathrm{L}$ & Bicarbonate & 195 & $\mathrm{mg} / \mathrm{L}$ & Bicarbonate & 195 & $\mathrm{mg} / \mathrm{L}$ \\
\hline Carbonate & 0 & $\mathrm{mg} / \mathrm{L}$ & Carbonate & - & $\mathrm{mg} / \mathrm{L}$ & Carbonate & 0 & $\mathrm{mg} / \mathrm{L}$ & Carbonate & - & $\mathrm{mg} / \mathrm{L}$ \\
\hline Chloride (Cl-) & 23 & $\mathrm{mg} / \mathrm{L}$ & Chloride (Cl-) & 23 & $\mathrm{mg} / \mathrm{L}$ & Chloride (Cl-) & 23 & $\mathrm{mg} / \mathrm{L}$ & Chloride (Cl-) & 23 & $\mathrm{mg} / \mathrm{L}$ \\
\hline Cyanide, Total & $<10$ & $\mu \mathrm{g} / \mathrm{L}$ & Cyanide, Total & - & $\mu \mathrm{g} / \mathrm{L}$ & Cyanide, Total & $<10$ & $\mu \mathrm{g} / \mathrm{L}$ & Cyanide, Total & - & $\mu \mathrm{g} / \mathrm{L}$ \\
\hline Cyanide, WAD & $<10$ & $\mu \mathrm{g} / \mathrm{L}$ & Cyanide, WAD & $<10$ & $\mu \mathrm{g} / \mathrm{L}$ & Cyanide, WAD & $<10$ & $\mu \mathrm{g} / \mathrm{L}$ & Cyanide, WAD & $<10$ & $\mu \mathrm{g} / \mathrm{L}$ \\
\hline Fluoride & 1.01 & $\mathrm{mg} / \mathrm{L}$ & Fluoride & 1.01 & $\mathrm{mg} / \mathrm{L}$ & Fluoride & 1.01 & $\mathrm{mg} / \mathrm{L}$ & Fluoride & 1.01 & $\mathrm{mg} / \mathrm{L}$ \\
\hline Nitrogen, NH4 & 3.59 & $\mathrm{mg} / \mathrm{L}$ & Nitrogen, NH4 & 0.745 & $\mathrm{mg} / \mathrm{L}$ & Nitrogen, NH4 & 3.59 & $\mathrm{mg} / \mathrm{L}$ & Nitrogen, NH4 & 0.745 & $\mathrm{mg} / \mathrm{L}$ \\
\hline Nitrogen, NO3 & $\leq 0.05$ & $\mathrm{mg} / \mathrm{L}$ & Nitrogen, NO3 & 0.556 & $\mathrm{mg} / \mathrm{L}$ & Nitrogen, NO3 & $\leq 0.05$ & $\mathrm{mg} / \mathrm{L}$ & Nitrogen, NO3 & 0.556 & $\mathrm{mg} / \mathrm{L}$ \\
\hline Nitrogen, NO2 & $\leq 0.05$ & $\mathrm{mg} / \mathrm{L}$ & Nitrogen, NO2 & - & $\mathrm{mg} / \mathrm{L}$ & Nitrogen, NO2 & $\leq 0.05$ & $\mathrm{mg} / \mathrm{L}$ & Nitrogen, NO2 & - & $\mathrm{mg} / \mathrm{L}$ \\
\hline Sulfate (SO4) & 4160 & $\mathrm{mg} / \mathrm{L}$ & Sulfate (SO4) & 2430 & $\mathrm{mg} / \mathrm{L}$ & Sulfate (SO4) & 4160 & $\mathrm{mg} / \mathrm{L}$ & Sulfate (SO4) & 2430 & $\mathrm{mg} / \mathrm{L}$ \\
\hline Dissolved Metals & & & Dissolved Metals & & & Dissolved Metals & & & Dissolved Metals & & \\
\hline Calcium & 456 & $\mathrm{mg} / \mathrm{L}$ & Calcium & 235 & $\mathrm{mg} / \mathrm{L}$ & Calcium & 456 & $\mathrm{mg} / \mathrm{L}$ & Calcium & 235 & $\mathrm{mg} / \mathrm{L}$ \\
\hline Magnesium & 658 & $\mathrm{mg} / \mathrm{L}$ & Magnesium & 295 & $\mathrm{mg} / \mathrm{L}$ & Magnesium & 658 & $\mathrm{mg} / \mathrm{L}$ & Magnesium & 295 & $\mathrm{mg} / \mathrm{L}$ \\
\hline Potassium & 62.4 & $\mathrm{mg} / \mathrm{L}$ & Potassium & 47.7 & $\mathrm{mg} / \mathrm{L}$ & Potassium & 62.4 & $\mathrm{mg} / \mathrm{L}$ & Potassium & 47.7 & $\mathrm{mg} / \mathrm{L}$ \\
\hline Sodium & 256 & $\mathrm{mg} / \mathrm{L}$ & Sodium & 263 & $\mathrm{mg} / \mathrm{L}$ & Sodium & 256 & $\mathrm{mg} / \mathrm{L}$ & Sodium & 263 & $\mathrm{mg} / \mathrm{L}$ \\
\hline Metals, Total & & & Metals, Total & & & Metals, Total & & & Metals, Total & & \\
\hline Aluminum & 19.7 & $\mu \mathrm{g} / \mathrm{L}$ & Aluminum & 24.1 & $\mu \mathrm{g} / \mathrm{L}$ & Aluminum & 19.7 & $\mu \mathrm{g} / \mathrm{L}$ & Aluminum & 24.1 & $\mu \mathrm{g} / \mathrm{L}$ \\
\hline Arsenic & 238 & $\mu \mathrm{g} / \mathrm{L}$ & Arsenic & 113 & $\mu \mathrm{g} / \mathrm{L}$ & Arsenic & 238 & $\mu \mathrm{g} / \mathrm{L}$ & Arsenic & 113 & $\mu \mathrm{g} / \mathrm{L}$ \\
\hline Cadmium & $<1.0$ & $\mu \mathrm{g} / \mathrm{L}$ & Cadmium & - & $\mu \mathrm{g} / \mathrm{L}$ & Cadmium & $<1.0$ & $\mu \mathrm{g} / \mathrm{L}$ & Cadmium & - & $\mu \mathrm{g} / \mathrm{L}$ \\
\hline Chromium & $<1.0$ & $\mu \mathrm{g} / \mathrm{L}$ & Chromium & - & $\mu \mathrm{g} / \mathrm{L}$ & Chromium & $<1.0$ & $\mu \mathrm{g} / \mathrm{L}$ & Chromium & - & $\mu \mathrm{g} / \mathrm{L}$ \\
\hline Copper & $<5.0$ & $\mu \mathrm{g} / \mathrm{L}$ & Copper & 7.74 & $\mu \mathrm{g} / \mathrm{L}$ & Copper & $<5.0$ & $\mu \mathrm{g} / \mathrm{L}$ & Copper & 7.74 & $\mu \mathrm{g} / \mathrm{L}$ \\
\hline Iron & 24500 & $\mu \mathrm{g} / \mathrm{L}$ & Iron & 3180 & $\mu \mathrm{g} / \mathrm{L}$ & Iron & 24500 & $\mu \mathrm{g} / \mathrm{L}$ & Iron & 3180 & $\mu \mathrm{g} / \mathrm{L}$ \\
\hline Lead & 1.27 & $\mu \mathrm{g} / \mathrm{L}$ & Lead & $<1.0$ & $\mu \mathrm{g} / \mathrm{L}$ & Lead & 1.27 & $\mu \mathrm{g} / \mathrm{L}$ & Lead & $<1.0$ & $\mu \mathrm{g} / \mathrm{L}$ \\
\hline Manganese & 4280 & $\mu \mathrm{g} / \mathrm{L}$ & Manganese & 623 & $\mu \mathrm{g} / \mathrm{L}$ & Manganese & 4280 & $\mu \mathrm{g} / \mathrm{L}$ & Manganese & 623 & $\mu \mathrm{g} / \mathrm{L}$ \\
\hline Mercury & $<0.0002$ & $\mu \mathrm{g} / \mathrm{L}$ & Mercury & - & $\mu \mathrm{g} / \mathrm{L}$ & Mercury & $<0.0002$ & $\mu \mathrm{g} / \mathrm{L}$ & Mercury & - & $\mu \mathrm{g} / \mathrm{L}$ \\
\hline Nickel & $<5.0$ & $\mu \mathrm{g} / \mathrm{L}$ & Nickel & 5.83 & $\mu \mathrm{g} / \mathrm{L}$ & Nickel & $<5.0$ & $\mu \mathrm{g} / \mathrm{L}$ & Nickel & 5.83 & $\mu \mathrm{g} / \mathrm{L}$ \\
\hline Selenium & $<5.0$ & $\mu \mathrm{g} / \mathrm{L}$ & Selenium & - & $\mu \mathrm{g} / \mathrm{L}$ & Selenium & $<5.0$ & $\mu \mathrm{g} / \mathrm{L}$ & Selenium & - & $\mu \mathrm{g} / \mathrm{L}$ \\
\hline Silver & 9.2 & $\mu \mathrm{g} / \mathrm{L}$ & Silver & - & $\mu \mathrm{g} / \mathrm{L}$ & Silver & 9.2 & $\mu \mathrm{g} / \mathrm{L}$ & Silver & - & $\mu \mathrm{g} / \mathrm{L}$ \\
\hline Zink & 136 & $\mu \mathrm{g} / \mathrm{L}$ & Zink & 51.8 & $\mu \mathrm{g} / \mathrm{L}$ & Zink & 136 & $\mu \mathrm{g} / \mathrm{L}$ & Zink & 51.8 & $\mu \mathrm{g} / \mathrm{L}$ \\
\hline Data Source & Water, Bo & tle \#3 & Data Source & 4100 & & Data Source & Nater, Bo & ttle \#3 & Data Source & 4100 & \\
\hline
\end{tabular}

Figure 4. Cooling water treatment scenarios.

It is anticipated that any equipment used to support this facility will be rated for heavy industrial use with minimal maintenance requirements and the potential for remote monitoring. It is unknown, but anticipated, that the chiller/heat exchanger may require pre-filtration of the cooling medium.

\section{Belsperse Injection Estimation}

Belsperse ${ }^{\circledR} 161$ is a phosphorus-containing dispersant made up of phosphinopolyacrylates, or an acrylic acid polymer (additional information attached). It is felt that Belsperse 161 is a good calcium carbonate and calcium sulfate dispersant. It is especially effective under high stress and high temperature conditions. ${ }^{4}$

${ }^{4}$ Robert R. Cavano. “Polymers for cooling water treatment”, Water Matters, Scranton Associates, Inc., Part II, Copolymers Analyst, pp 1-14, Winter 2001. 
The Environmental Restoration Division at LLNL has been using Belsperse 161 for several years based on experiments done with air stripping equipment ${ }^{5}$. They found that Belsperse was much more effective for reducing scale buildup than the JP-7 polyphosphate formulation (Jaeger Products, Inc.). Their injection procedures call for feed rates initially based on stoichiometry, and adjusted according to field observations.

Estimations of Belsperse 161 injection concentrations, based on stoichiometric relationships, account for $\mathrm{pH}$, temperature, ion-species and inorganics. A spreadsheet calculator, developed by Tom Wolfe of Perlorica Inc. ${ }^{6}$ was used to obtain the required injection concentration for the various conditions anticipated by the design of the mine water cooling stream. A sample input page is shown as (Figure 5). Some critical analytical data, not provided in the scenario 2 and 4 data sets, were supplemented with values from Scenario 1 and 3 including Bicarbonate, Chloride and Flouride.

Based on Scenario 1, with temperatures reaching $140^{\circ} \mathrm{F}$ in the heat exchanger, the required Belsperse 161 concentration should be $0.63 \mathrm{mg} / \mathrm{L}$. For the flow rate of $300 \mathrm{gpm}$ this would require an injection rate of $1.3 \mathrm{ml} / \mathrm{min}$ of $50 \%$ belsperse solution. The concentrations and flow rates for the other scenarios are listed in Table 1. It's likely that higher flow rates would be imposed to account for variations in water chemistry.

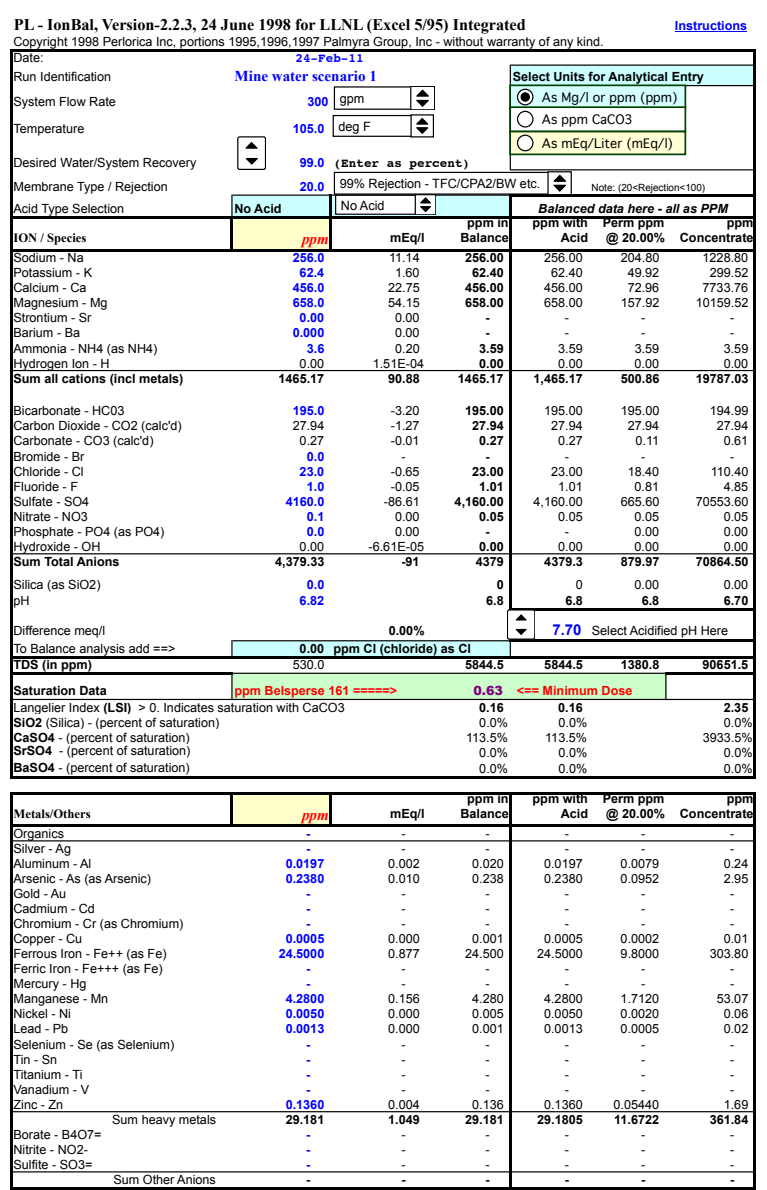

Figure 5. Belsperse 161 calculation input page for Scenario 1.

${ }^{5}$ P. W. Krauter, “Test of a Chemical Dispersant for the Control of Scale Formation at Treatment Facility D”, May 1998, UCRL-ID-130568 ${ }^{6} \mathrm{PL}$ - IonBal, Versio

n-2.2.3, 24 June 1998 for LLNL (Excel 5/95), Copyright 1998 Perlorica Inc, portions 1995,1996,1997 Palmyra Group, Inc 
Table 1. Belsperse injection calculation results for all scenarios.

\begin{tabular}{rcccc} 
& \multicolumn{3}{c}{ Scenario } \\
Treatment Parameters & 1 & 2 & 3 & 4 \\
\hline Process flow rate $(\mathrm{gpm})$ & 300 & 300 & 600 & 600 \\
Process temperature $\left({ }^{\circ} \mathrm{F}\right)$ & 105 & 105 & 105 & 105 \\
Belsperse 161 concentration $(\mathrm{mg} / \mathrm{L})$ & 0.63 & 2.2 & 0.63 & 2.2 \\
Belsperse 161 injection rate $(\mathrm{ml} / \mathrm{min})$ & 1.3 & 4.5 & 2.6 & 9 \\
Belsperse solution usage $(\mathrm{gal} / \mathrm{day})$ & 0.5 & 1.8 & 1 & 3.6
\end{tabular}

\section{Preliminary Treatment System Design}

A chemical injection system to support the facility described above should include the following:

A. Chemical holding/mixing tanks.

B. Delivery/metering pump

C. Injection hardware

The chemical holding tanks could be lined drums, polyethylene tanks or FRP vessels. These vessels should not be open to the atmosphere. Very clean water should be used to dilute the Belsperse 161. Nondiluted Belsperse is very viscous and can be problematic to pump and meter as it tends to crystalize easily.

The metering pump should have self calibration or an intrinsic calibration system. The pump could be a diaphragm pump similar to the LMI series pumps (Figure 6). The pumps should be rated to allow injection pulses no less frequent than once per 2 seconds. Remote metering and adjustment are possible with these pumps.

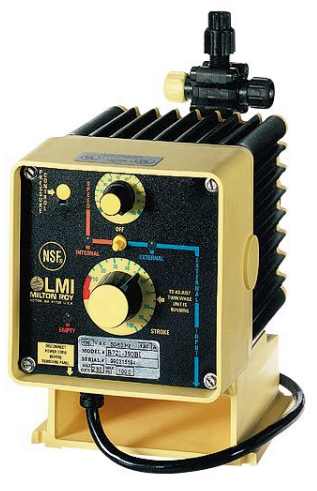

Figure 6. Typical LMI metering pump.

The flow from the "treatment" system to the heat exchanger has a Reynolds number varying from 1.7E5 to 3.4E5. This is neither turbulent nor laminar, but in the "transition" zone. Although the length of the pipeline is significant, it may not be prudent to count on sufficient mixing within this section. It is recommended that a pre-mixer be used to facilitate more thorough mixing (Figure 7). This would include a side stream injection line with a static mixer that would re-enter the main line through an injection probe. This would also facilitate easier maintenance with isolation valves on either end of the pipeline. 


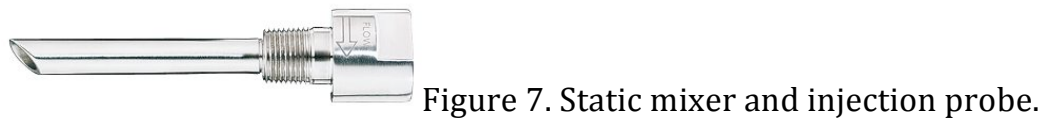

All of the appropriate leak detection, check valves and monitoring devices should be employed to ensure that the injection system isn't a weak link in the chain for leaks. A rough layout for an injection system is given as Figure 8.

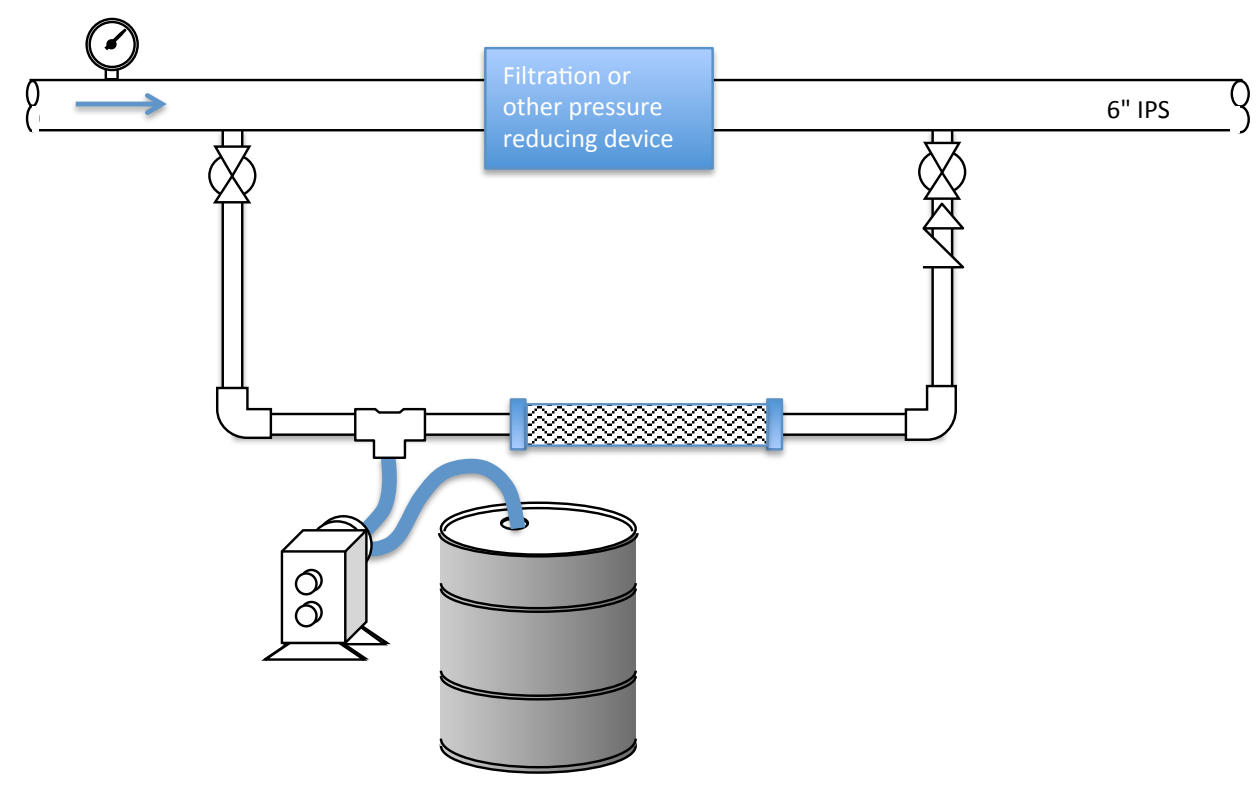

Figure. 8 Diagram of potential injection system.

\section{Conclusions}

Based on the water chemistry it is anticipated that there is a high likelihood for sulfate compound precipitation and scaling. This may be dependent on the temperature and pressure, which vary throughout the system. Therefore, various types and amounts of scaling may occur at different locations. Although it has been shown that decreased pressure causes increased scaling, it is unclear if this condition will have significant affect, as all the pressures are low. Sulfate concentrations predominate, but there is still a chance for calcium carbonate buildup, especially in the heat exchanger where the temperatures are rising.

Additional information is needed to conduct a thorough analysis, but it would appear that a fairly simple injection system would be sufficient to address scaling issues.

It would be advisable to:

1. Take additional samples of the water to confirm a tighter range of analytical values for a broader list of analytes.

2. Get detailed design information about the chiller/heat exchanger and its effect on the water temperature and pressure drop. 
3. Consult with an organization, such as Intertek ( http://www.intertek.com/oil-andgas/exploration-and-production/scale/), that has experience with this type of treatment system.

4. Do field tests to determine the effectiveness and accuracy of the preliminary design.

\section{Belsperse ${ }^{\circledR} 161$ Dispersant - General Product Information}

Belsperse 161 dispersant has been developed as a highly effective scale control agent and dispersant used primarily in boilers and industrial cleaning.

The active ingredient of Belsperse 161 is a phosphinocarboxylic acid.

\section{Typical Physical Properties}

Appearance

Odor

Solids content

Specific gravity

$\mathrm{pH}$ (undiluted)

Viscosity at $25^{\circ} \mathrm{C}$

Boiling point range

Freezing point range

Theoretical phosphorus

content (as P)

Solubility in:

- water

- ethylene glycol

- methanol

- $46 \%$ caustic soda

$\mathrm{pH}$ limitations

Colorless liquid

Slight

$50 \%(w / w)$

$1.20-1.24$

3.5-4.5

$90-150 \mathrm{cSt}$

$101-103^{\circ} \mathrm{C}\left(213-217^{\circ} \mathrm{F}\right)$

-1 to $-3^{\circ} \mathrm{C}\left(30-27^{\circ} \mathrm{F}\right)$

$0.8 \%(w / w)$

Miscible

Miscible

Precipitate is formed

Miscible

Does not form insoluble sodium or potassium

salts. It is hydrolytically

stable and can be

incorporated into

concentrated

formulations regardless

of the final $\mathrm{pH}$.

\section{Thermal stability (DSC)}

Differential scanning calorimetry has shown that

Belsperse 161 is stable up to a temperature of $200^{\circ} \mathrm{C}$ $\left(392^{\circ} \mathrm{F}\right)$.

\section{Chemical reactivity}

Belsperse 161 is not affected by chlorine or other oxidising biocides under normal use conditions.

Further details on safety and handling are available in the materials safety data sheet on this product.

\section{Logistics \\ Classification \\ Packaging}

non-hazardous for conveyance non-hazardous for supply HDPE 220I XL-ring Mauser drum

Height $935 \mathrm{~mm}$

Diameter $580 \mathrm{~mm}$

Gross weight $544 \mathrm{lb}$

Net weight $525 \mathrm{lb}$

Regulatory approvals

FDA 21 CFR 173.310 - boiler additives

USDA G5: cooling and retort water

G6: boilers and steamlines - possible

food contact

G7: boilers, steamlines and cooling systems - no food contact

A1: cleaning compounds; meat/poultry plants

B2/B2: laundry compounds; meat/poultry plants

Q1: shell egg cleaning; meat/poultry plants

\section{Toxicology data}

Acute oral LD $\mathrm{LD}_{50}$ (rats) $>5000 \mathrm{mg} / \mathrm{kg}$

Eye irritation (rabbits) Non-irritant (EEC guidelines)

Skin irritation (rabbits) Non-irritant (EEC guidelines)

Toxicity to fish:

- rainbow trout 96-hr $\mathrm{LC}_{50}>1000 \mathrm{mg} / \mathrm{l}$

- zebra fish 96-hr $L_{50}>1000 \mathrm{mg} / \mathrm{l}$

\section{Ecological data}

96-hr LC 50 (brown $\quad>10000 \mathrm{mg} / \mathrm{l}$

shrimp)

24-hr EC 50 (daphnia) >320 mg/l

72-hr EC 50 (algae $\quad 130 \mathrm{mg} / \mathrm{l}$

inhibition)

COD

Biodegradation
$890 \mathrm{mg} \mathrm{O}_{2} / \mathrm{g}$

Not readily biodegradable $20 \%$ in 28 days (OECD301E) 